\title{
The Role of Appraisals in Energy Efficiency Financing
}

Victoria Doyle and Abhay Bhargava Building Industry Research Alliance

May 2012 


\title{
This report received minimal editorial review at NREL
}

\begin{abstract}
NOTICE
This report was prepared as an account of work sponsored by an agency of the United States government. Neither the United States government nor any agency thereof, nor any of their employees, subcontractors, or affiliated partners makes any warranty, express or implied, or assumes any legal liability or responsibility for the accuracy, completeness, or usefulness of any information, apparatus, product, or process disclosed, or represents that its use would not infringe privately owned rights. Reference herein to any specific commercial product, process, or service by trade name, trademark, manufacturer, or otherwise does not necessarily constitute or imply its endorsement, recommendation, or favoring by the United States government or any agency thereof. The views and opinions of authors expressed herein do not necessarily state or reflect those of the United States government or any agency thereof.
\end{abstract}

Available electronically at http://www.osti.gov/bridge

Available for a processing fee to U.S. Department of Energy

and its contractors, in paper, from:

U.S. Department of Energy

Office of Scientific and Technical Information

P.O. Box 62

Oak Ridge, TN 37831-0062

phone: 865.576.8401

fax: 865.576 .5728

email: mailto:reports@adonis.osti.gov

Available for sale to the public, in paper, from:

U.S. Department of Commerce

National Technical Information Service

5285 Port Royal Road

Springfield, VA 22161

phone: 800.553 .6847

fax: 703.605 .6900

email: orders@ntis.fedworld.gov

online ordering: http://www.ntis.gov/ordering.htm

Printed on paper containing at least $50 \%$ wastepaper, including $20 \%$ postconsumer waste 


\title{
The Role of Appraisals in Energy Efficiency Financing
}

\author{
Prepared for: \\ Building America \\ Building Technologies Program \\ Office of Energy Efficiency and Renewable Energy \\ U.S. Department of Energy
}

Prepared by:

Victoria Doyle and Abhay Bhargava

Building Industry Research Alliance

7407 Tam O’Shanter Drive

Stockton, CA 95205

NREL Technical Monitor: Chuck Booten

Prepared Under Subcontract No. KNDJ-0-40343-00

May 2012 


\section{Acknowledgments}

This work is sponsored by the U.S. Department of Energy (DOE), Office of Energy Efficiency and Renewable Energy, Building America Program under cooperative agreement number DEFC26-06NT42767. This support does not constitute DOE endorsement of the views expressed in this report. 


\section{Contents}

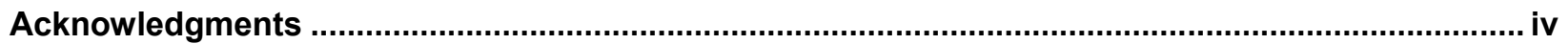

List of Figures

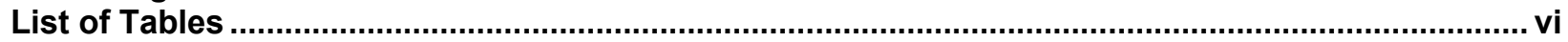

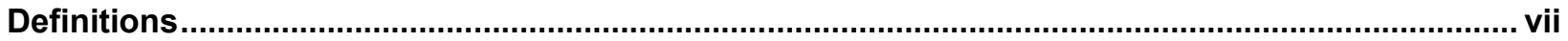

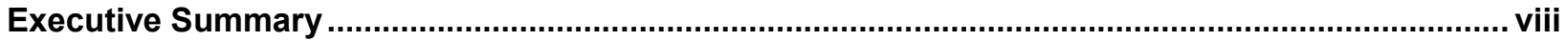

1 Introduction

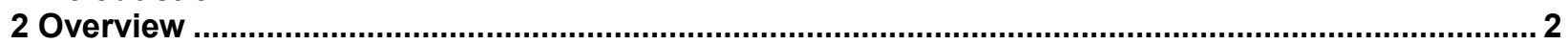

2.1 Status of Energy Efficiency Financing ......................................................................2

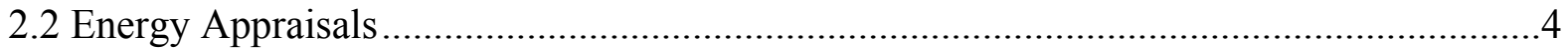

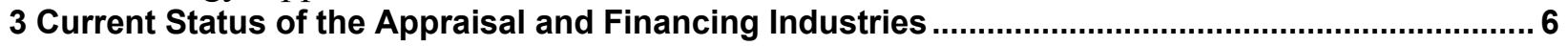

3.1 Barriers to Appraising Energy Efficiency..............................................................6

3.1.1 Limited Interactions Between Stakeholders (Lenders, Appraisers, and

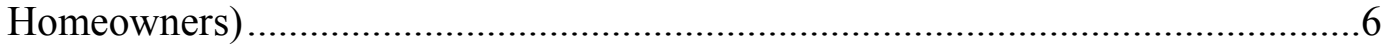

3.1.2 Lack of Comparables and Valuation Data ......................................................... 7

3.1.3 Current Housing Market and National Economic Hardship ..................................

3.1.4 Downturn in Housing Market .........................................................................

3.1.5 Variabiations in Occupant Behaviors and Weather Conditions ........................... 7

3.1.6 Knowledge Gaps in the Lending and Housing Industries ..................................

3.1.7 Lack of Energy Efficiency Appraisal Training and Education..............................8

3.1.8 Resistance to Change: Traditional Home Appraisal Methods ................................

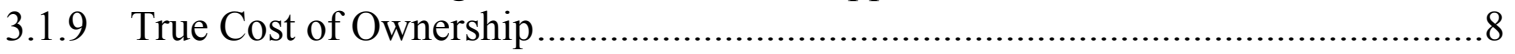

3.2 Appraisal Industry Developments for Valuing Energy Efficiency ..................................8

3.2.1 Dodd-Frank Wall Street Reform and Consumer Protection Act (HR 4173) ..........9

3.2.2 Introduction of Sustainable Building Science Education and Certification ............9

3.2.3 Green MLS Tool Kit....................................................................................

3.2.4 Appraisal Institute Addendum ...................................................................... 10

3.2.5 Sensible Accounting to Value Energy Act ................................................... 10

3.3 Improving Energy Efficiency Valuation Methods.......................................................... 11

3.3.1 Identify Renewable Energy and Energy Efficiency Measures ............................11

3.3.2 Obtain a Home Energy Evaluation Report ....................................................11

3.3.3 Assess the Value of Energy Efficiency Measures ............................................ 12

3.4 Learning From Models Used in Commercial Appraisals ........................................... 12

3.4.1 Comparison With Documented Historical Data ............................................. 12

3.4.2 Factoring in Operating Costs ..................................................................... 13

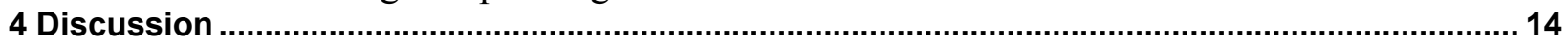

4.1 Next Steps Toward Market Transformation ............................................................. 14

4.1.1 Increase Interactions Between Stakeholders......................................................14

4.1.2 Close Knowledge Gaps in Lender and Housing Industry ..................................15

4.1.3 Develop and Expand Appraiser Education ......................................................15

4.1.4 Update Traditional Home Appraisals Methods ................................................15

4.1.5 Develop Comparables and Valuation Database ...............................................16

4.1.6 Understand Associated Risks of Variations in Occupant Behaviors, Plug Loads,

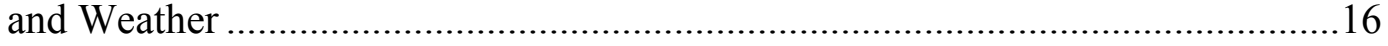

4.2 Current Opportunities to Ensure the Proper Valuation of an Energy-Efficiency

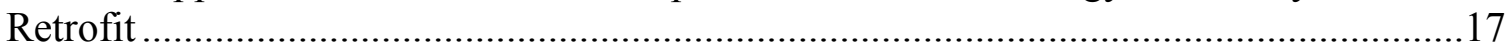

4.2.1 Request Quality Green Building Competence ............................................... 17 
4.2.2 Require Access to Valuation Guides

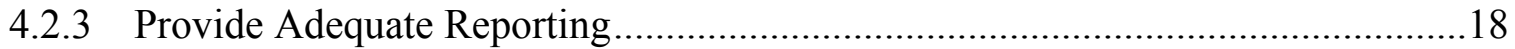

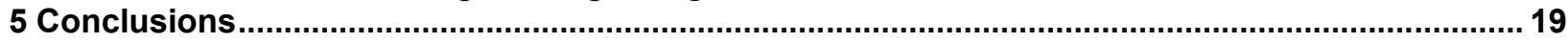

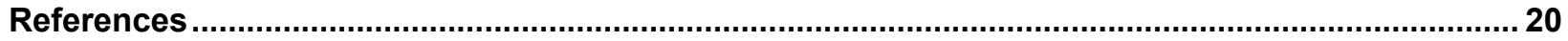

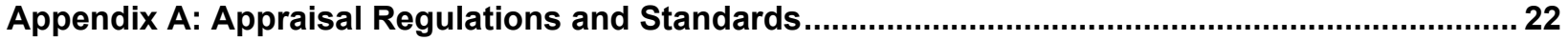

\section{List of Figures}

Figure 1. Average annual homeowner costs in 2008: Energy costs are homeowner's second largest annual housing expenses (if mortgage payments are included as well) .................. 3

Figure 2. Example of monthly costs before and after energy efficiency retrofit: The incremental costs for financing an energy efficiency retrofit can provide homeowners a net positive cash flow.

\section{List of Tables}

Table 1. True Cost of Homeownership: An Example of Typical Home Costs Compared to a Home With an Energy Efficiency Retrofit

Table 2. Recommended Minimum Criteria for State Licensed/Certified Appraisers 


\section{Definitions}

AMC
BIRA
Fannie Mae
FHA
Freddie Mac
HUD
HVCC
LEED
MLS
NAR
PACE
SAVE

Appraiser Management Companies

Building Industry Research Alliance

Federal National Mortgage Association (FNMA)

Federal Housing Authority

Federal Home Loan Mortgage Corporation (FHLMC)

U.S. Department of Housing and Urban Development

Home Valuation Code of Conduct

Leadership in Energy and Environmental Design

Multiple listing service

National Association of Realtors

Property-assessed clean energy

Sensible Accounting to Value Energy Act 


\section{Executive Summary}

As the U.S. Department of Energy's Building America program continues to research all facets of the residential building industry and develop cost-effective, energy-efficient building strategies and measures, there is a need to address one of the major barriers to the implementation of these measures and strategies in the field-homeowners' ability and motivation to finance these in new construction as well as retrofits. The current energy efficiency financing options are being driven (and in turn limited) by first being able to identify energy efficiency improvements, understanding the potential added value of implementing these measures and strategies, and then accounting for these in the home appraisal report. Homeowners are thus challenged with securing financing for energy efficiency improvements, often because home appraisal reports do not document energy efficiency improvements, and do not associate added value from energy efficiency improvements.

There is a cyclical interdependence of numerous industry stakeholders and factors toward shaping the market — both the value and the perception. Appraisers cannot create value and market demand directly; however, they are key stakeholders for successful market transformation.

This research identifies these barriers and challenges, current industry status (including several key appraisal industry developments for identifying and valuing energy efficiency), critical obstacles to documenting and assessing the potential added value from energy efficiency improvements, current opportunities to support and standardize reporting about energy efficiency and to ensure proper valuation, and next steps toward enabling energy efficiency financing market transformation. Evaluations of current and pending industry regulations, policies, and standards indicate that critical concerns from stakeholders are being addressed. These are efforts to increase opportunities to identify and properly valuate energy efficiency, and to improve market uptake of and secure financing for energy efficiency retrofits. 


\section{Introduction}

This Building Industry Research Alliance (BIRA) report addresses the current challenges, issues, and recommended next steps to address one of the major barriers to the implementation of energy efficiency strategies and measures in homes - energy efficiency financing, and its accounting in home appraisals. BIRA has conducted industry research about the relationship between appraising the value of energy efficiency in homes and financing energy efficiency upgrades to homes. This report includes a brief background on home appraisals and retrofit financing, summarizes finding from industry research, and discusses barriers to identifying and valuing energy efficiency improvements, and recommended next steps. Due to the extensive breadth and depth of this topic, this report addresses appraisals and financing for existing, singlefamily, detached homes only. BIRA has also identified issues driving homeowners' ability and motivation to finance energy-efficient features and strategies in home energy retrofits.

In this report, improving energy efficiency refers to reductions in energy consumption for the whole house, including heating, cooling, lighting, and appliances, over a certain period of time. The likely benefits to homeowners of increasing their homes' energy efficiency include reduced energy bills, increased comfort and indoor air quality, and lowered carbon footprints. Simple and affordable financing options would help to encourage homeowners to improve the energy efficiency in the approximately 130 million homes in the United States. However, currently the home appraisal process does not customarily recognize energy efficiency measures (EEMs) or account for the potential added value (e.g., cost savings) from energy efficiency improvements. Without documenting the EEM and accounting for the energy efficiency cost benefits and value, lenders are often not able to provide the homeowner adequate financing options for making energy efficiency improvements. To fully realize the value of energy-efficient homes, homeowners and lenders need to engage with appraisers, documenting and demonstrating the financial benefits and risks of energy efficiency improvements. 


\section{Overview}

Energy efficiency retrofit financing is a means of purchasing home improvements that will increase the energy efficiency of the home and thereby lower monthly utility bills. Energy efficiency retrofit financing can be part of a large financing transaction (e.g., mortgage refinance), or a relatively small, standalone loan (e.g., a personal line of credit) to pay for energy efficiency improvements in the home.

\subsection{Status of Energy Efficiency Financing}

In early 2011, BIRA researched various financing programs in order to provide homeownerseither directly or through a contractor, program administrator or other energy efficiency industry parties - guidelines covering the available energy efficiency retrofit financing options with details to access them. This research reviewed and documented the barriers, technical data requirements, tradeoffs, risks, and underwriting opportunities for Energy Efficient Mortgage Refinance; FHA 203(k) Rehabilitation Mortgage; HUD Title I Home Improvement Loans; Power Purchase Agreements; Revolving Loan Funds; Property Assessed Clean Energy; On-Bill Financing; third-party loans; and general lines of credits/unsecured home improvement loans. Despite the availability of numerous energy efficiency retrofit financing products, such as those listed here, homeowners are often still not able to obtain the expected increase in home values when completing an energy efficiency retrofit, and consequently are not encouraged to invest in energy efficiency.

Currently, financing for energy efficiency retrofits of existing homes is limited by the current methodology used for loan risk analysis. Customary underwriting is commonly summarized as an assessment of three factors: (1) the prospective borrower's creditworthiness (usually represented by borrower's credit history of paying other accounts on time); (2) an assessment of property value to confirm and assess resale value in the event of default; and (3) an assessment of the borrower's ability to make the mortgage payments on time - net income and assets that can be called on to make the monthly payments. Current underwriting and home appraisals do not consider certain costs of homeownership, specifically energy costs.

Current underwriting methods and guidelines were predominantly developed in the 1940s, and have not evolved significantly since then. During the initial development of the traditional underwriting process, energy costs were relatively low and steady and were therefore not seen to be important enough to be accounted for in the process. Furthermore, most houses were similarly constructed without investments in energy efficiency. The current energy and housing markets do not reflect these conditions anymore. The energy costs of a house represent a significant portion of a homeowner's monthly budget (see Figure 1). 


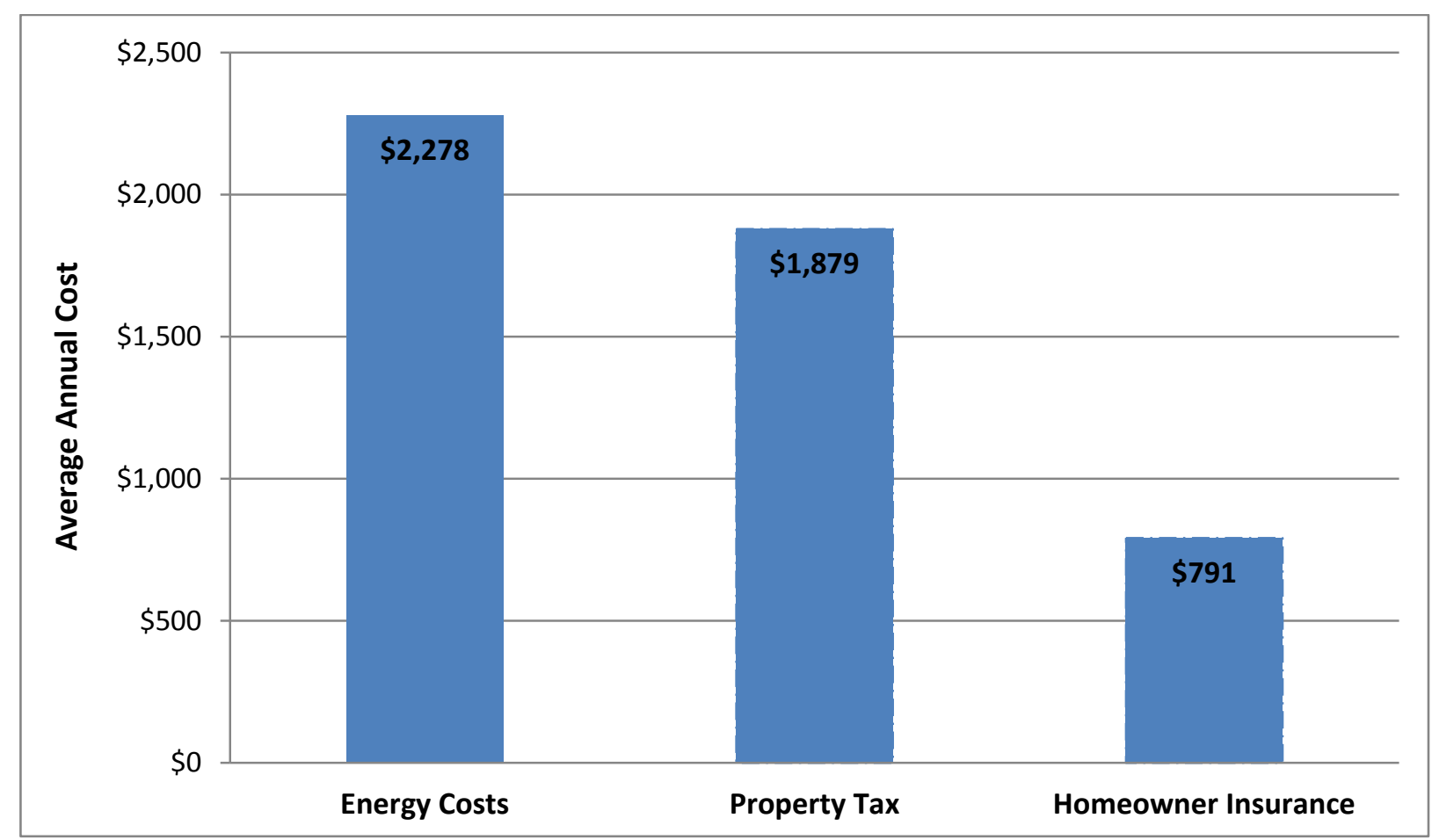

Figure 1. Average annual homeowner costs in 2008: Energy costs are homeowner's second largest annual housing expenses (if mortgage payments are included as well).

(Institute for Market Transformation 2008)

No longer are energy costs relatively low, or even steady. Energy costs have risen steeply over the past 60 years and are expected to continue rising. Moreover, building codes with efficiency requirements have raised awareness in the housing market about the comfort and cost differences between highly energy-efficient homes and regular homes.

Thus, in light of this evolution of the energy and housing markets, the current methods for home appraisals are no longer sufficient to appropriately account for these significant changes. An underwriter uses the data presented in the appraisal report to determine optimal loan value. Typically, loan amounts are limited to the value stated in the appraisal report. Current appraisal reports do not account for energy costs of a house - an unavoidable cost of homeownership, and energy efficiency retrofit loans often receive limited financing as a result. Furthermore, when a more energy-efficient home (with energy-efficient features installed) is put up for sale, the home value from the appraisal report hinders the seller's ability to receive a return on investment from an energy efficiency improvement. Homeowners are thus challenged with securing financing for energy efficiency improvements, often because home appraisals do not account for the added value from energy efficiency improvements. However, the added value of energy efficiency can be seen from the positive net cash flow (see Figure 2) to the homeowner, after an energy efficiency retrofit. 


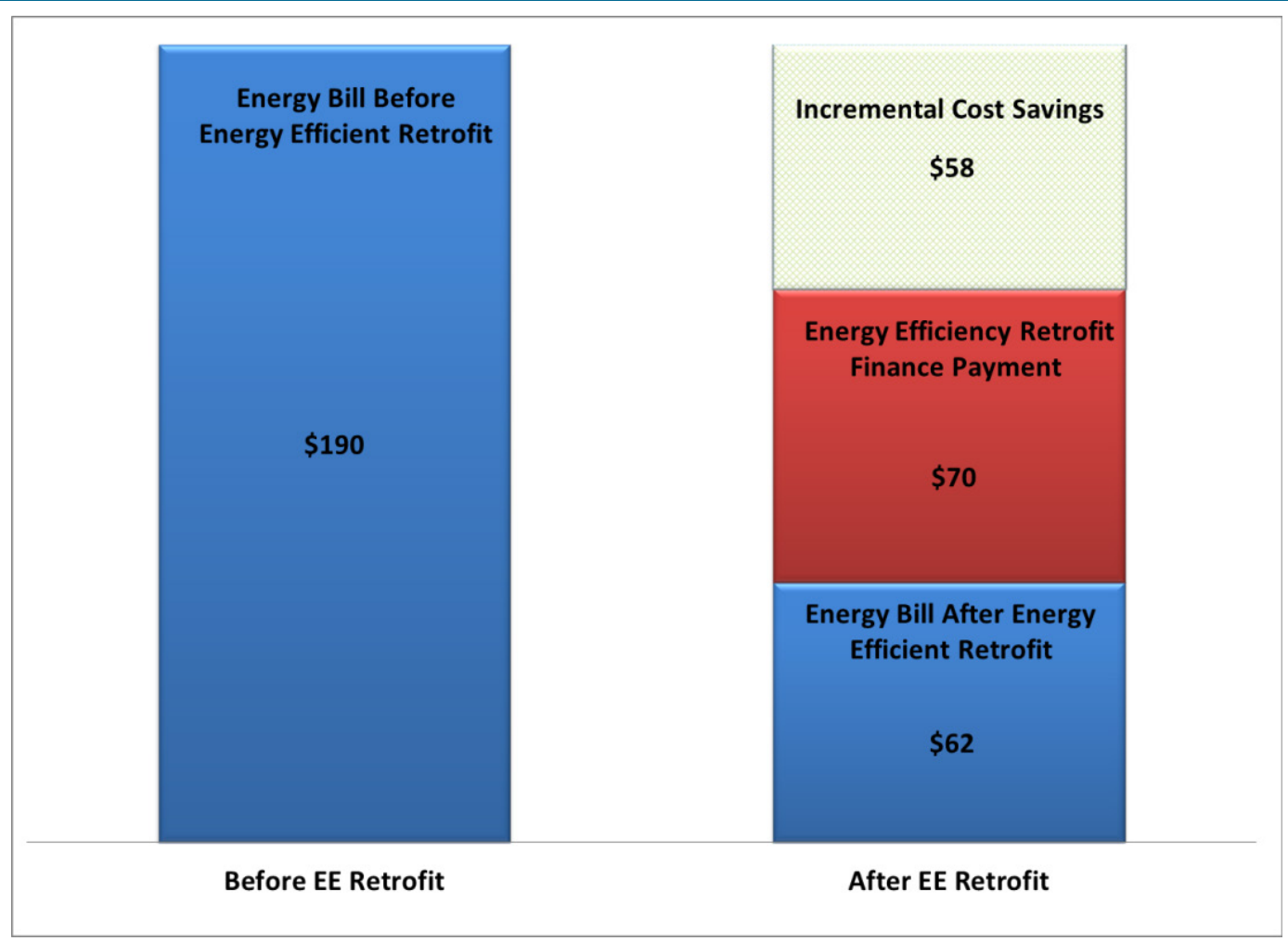

Figure 2. Example of monthly costs before and after energy efficiency retrofit: The incremental costs for financing an energy efficiency retrofit can provide homeowners a net positive cash flow.

Figure 2 illustrates an example of the effects of installing and financing energy efficiency improvements. A homeowner will be responsible for repaying the energy efficiency loan, but the resulting energy savings can correspond to significant month utility bill savings. Any cumulative, monthly cost differences from before the energy efficiency retrofit to after, are cost savings to the homeowners. Cost savings will vary based on factors including the energy efficiency and the cost of the retrofit measures, loan parameters (such as interest rates and terms), as well as the homeowner's energy consumption behavior. The left bar represents the energy utility costs alone prior to retrofit, and the right bar represents the reduced utility costs, the monthly financing cost of the retrofits, and the potential for monthly savings, given a retrofit optimized for cash flow. For example, a homeowner can invest $\$ 12,000$ in an energy efficiency retrofit, financed with a 30 -year loan at 5.5\% interest, resulting in a $\$ 70$ month loan payment. If the retrofit results in a reduction in energy cost by two thirds, the average home energy costs could be reduced to $\$ 62$, and the net difference in monthly homeowner cash flow is positive.

\subsection{Energy Appraisals}

Appraisers play a pivotal role in lending and financing decisions. An appraiser's valuation of a home and accompanying assessment of home improvements provide the necessary independent third-party assessment. These appraisals serve as a qualifying mechanism on which a lender decides to approve or deny a loan, and accompanying variables - loan amount, period, and interest rates. A home appraisal is a survey and analysis of a home by a licensed professional appraiser for an assessment of the property market value. In many cases, an appraisal is requested by a financial lender when a home is being evaluated for a home improvement loan. The home appraisal results in a detailed report that looks at items such as the condition of the 
home, its neighborhood, what similar homes are selling for, and how quickly similar homes sell. A home appraisal report provides lenders with documented evidence and data about current market preferences and estimates of home value, both before and after any intended home improvements.

The role of the appraiser is to be a translator and to provide an independent third-party perspective. A home appraisal requires the appraiser to identify, comprehend, and communicate the features (currently excluding EEMs) of the property, the benefits that accrue from those features, and the market acceptance, all of which contribute to the opinion of market value. Appraisers do not create value; they only analyze and report the market's direction and perceptions based on industry evidence and data. Lenders use the appraiser's market value opinion as an objective observation of the home and the marketplace.

The appraiser will evaluate the home by reviewing information retrieved from a physical site inspection, the property's tax records, and multiple listing service (MLS) databases. The appraiser analyzes and accounts for a number of factors such as the condition of the home, the neighborhood, what similar homes are selling for, and how quickly similar homes are sold.

There are three customary methods for valuing a home: (1) the cost approach (the cost to replicate the house in its current location); (2) the sales comparison analysis (compares the home values from similar local homes); and 3) the income method (typically used only if the home is in an area with a significant number of rental properties). Currently all three methods are being used without factoring in the energy efficiency impacts or energy cost savings resulting from the energy efficiency improvements in the homes. 


\section{Current Status of the Appraisal and Financing Industries}

The dynamic relationship between home appraisals and energy efficiency financing has proved be a multifaceted issue, with varying concerns from both industries. As BIRA's research showed, financing tools are available for energy efficiency retrofits, but are limited (BIRA 2011a). One of the primary gaps in financing energy efficiency retrofits for homeowners is obtaining proper valuation for energy efficiency improvements. In the appraisal industry, research indicates the challenges to providing proper valuation of an energy-efficient home are numerous as well.

As a significant part of BIRA's appraisal and financing industry research, BIRA hosted a Building America Expert Meeting on June 21, 2011 (BIRA 2011b). This meeting provided a forum for presentations and discussions about the relationship between appraising the value of energy efficiency in homes and financing energy efficiency upgrades to a home. Information and industry knowledge collected from the meeting were leveraged for this report. Following the expert meeting, significant industry research was performed by BIRA about the status of industry developments and barriers to the proper valuation of energy efficiency improvements.

\subsection{Barriers to Appraising Energy Efficiency}

To successfully implement energy efficiency improvements in the residential sector on a nationwide scale, there are several barriers that will need to be addressed. Appraisers depend on the industry's ability to provide adequate resources (e.g., valuation data, standardize assessment methods, and education).

The financing industry depends on the appraisal industry's ability to ascertain the expected market value for any and all homes, including those with energy efficiency improvements. Given this interdependent and dynamic relationship, it is important to recognize that the barriers to proper valuation of energy efficiency improvements stem from both industries. Without accessible resources, appraisers will not be able to properly value energy efficiency, and financing will in turn not be able to supply sufficient loans for energy efficiency improvements. Current industry barriers include:

\subsubsection{Limited Interactions Between Stakeholders (Lenders, Appraisers, and Homeowners)}

Despite the strong interdependence of the appraisal and financing industries, such restricting standards as the Home Valuation Code of Conduct (HVCC) prohibited homeowners and lenders from communicating directly with appraiser (FHFA 2008). Although effectively replaced with the Dodd-Frank Wall Street Reform and Consumer Protection Act (Frank 2009) (more information in Section 3.2), the HVCC had essentially required all communication to be channeled through an Appraiser Management Company (AMC). It is then the responsibility of the AMC to evaluate competency and assign appraisal jobs based on knowledge and skills sets. Unfortunately, this is often not the case and the AMC typically selects an appraiser from a preapproved list with little to no regard for areas of expertise or competency. In most AMCs, jobs are offered on a rotational basis. This issue represents a significant barrier to ensuring energy efficiency improvements are properly valued. 


\subsubsection{Lack of Comparables and Valuation Data}

An appraiser relies heavily on market evidence to estimate value. Comparable sales, surveys of property performance, and return expectations are currently unavailable in most markets. Objective data will enable an appraiser to assess the source and impact of the data without hesitation. In the current market with limited data, appraisers have resorted to assessing arbitrary values for energy efficiency improvements. For example, in Tallahassee, Florida, the appraisal standard is to add $\$ 3,000$ to a home's market value if it has an energy efficiency certification, irrespective of its size or specific features.

\subsubsection{Current Housing Market and National Economic Hardship}

The current housing market and economic hardship have resulted in significant lowering of the value of homes. Homeowners and appraisers are still coming to terms with the lower valuations.

\subsubsection{Downturn in Housing Market}

The downturn in the housing market has resulted in a decrease in demand for appraisals. Professionals who have been able to secure income from appraisals are often struggling to do so and cannot afford or justify additional training and education for assessing energy efficiency improvements. The national economic hardship has affected everyone, but has been especially challenging to homeowners, as average home values decreased substantially. Homeowners are still challenged with a restrictive credit market. With the loss of home equity, homeowners requesting home improvement (e.g., energy efficiency improvement) loans are often turned away by lenders.

\subsubsection{Variabiations in Occupant Behaviors and Weather Conditions}

Appraisers and lenders are concerned about the multiple variables associated with energy efficiency estimates. Variations in occupant behaviors, plug loads, and weather conditions can all have significant impacts on the actual energy consumption of a home. Typical energy simulations account for such variables based on regional averages. For analysis purposes, the average variation is acceptable; however, for appraisers concerned with liability and lenders concerned with return on investments, the variation can present too much risk. It is important for those in the industry to recognize the level of risk associated with energy modeling and to factor the risk appropriately.

\subsubsection{Knowledge Gaps in the Lending and Housing Industries}

It is the appraiser's responsibility to assess the market value of a home; it is the underwriter's responsibility to understand and use the appraisal data and market value estimate appropriately. The underwriter will be assessing the risk; therefore, it is vital that he or she is trained and educated about the benefits of energy efficiency improvements. Also, professionals directly involved in the housing market, such as real estate professionals (agents) and general contractors, should be well versed in fundamental building science and have a working knowledge of energy efficiency principles. Although there have been (and continue to be) significant advances made in the appraisal industry about regulations and standards for valuing energy efficiency, the other interdependent industries (e.g., financing and housing) have not raised significant awareness about these changes. Currently these industries are not knowledgeable about energy efficiency and consequently cannot provide adequate support for valuing and financing energy efficiency improvements. 


\subsubsection{Lack of Energy Efficiency Appraisal Training and Education}

Based on industry research, an ongoing barrier to appraising energy efficiency improvements is lack of training and education for the appraiser. Often, appraisers are confused about the various green and energy efficient construction programs, the functionality of the Home Energy Rating System (HERS) scores, where they can receive information about energy efficiency, and how to provide a value comparison. All states require education, experience, and licensing for appraisers, but energy efficiency requires a different kind of knowledge and appraiser licensing does not recognize this specialty as distinct. Moreover, the lack of accessible education about energy efficiency causes some appraisers to be disgruntled by some of the new standards and requirements for assessing energy efficiency. The housing industry is already depressed and some appraisers believe that it is not acceptable to expect appraisers to be experts in the everevolving energy-efficient housing market.

\subsubsection{Resistance to Change: Traditional Home Appraisal Methods}

The current method has not changed substantially since its development in the 1940s. Appraisers have been trained to provide market valuations for aesthetic and structural improvements. Until recently, the industry did not recognize energy efficiency as a factor in homeownership cost or property value. The customary method currently used for home appraisals fails to take into account the long-term economic benefits of energy efficiency improvements. This limitation leads to hindered financing and lower sales listing prices. It is vital that the appraisal industry recognizes true homeownership costs.

\subsubsection{True Cost of Ownership}

The true cost of home ownership (i.e., factoring in cash flow) for an energy-efficient home can be less than the true cost of homeownership for a comparable home. Shown in Table 1, the energy-efficient home price is higher than that of an older home; however, the reduced utility bill cost offsets the energy improvement costs, resulting in total monthly saving for the homeowner.

Table 1. True Cost of Homeownership: An Example of Typical Home Costs Compared to a Home With an Energy Efficiency Retrofit

\begin{tabular}{c|c|c}
\hline & $\begin{array}{c}\text { Older Existing } \\
\text { Home }\end{array}$ & $\begin{array}{c}\text { Same Home With } \\
\text { Energy Improvements }\end{array}$ \\
\hline $\begin{array}{c}\text { Home Price } \\
(\mathbf{9 0 \%} \text { mortgage, 8\% interest) } \\
\text { Loan Amount } \\
\text { Monthly Payment } \\
\text { Utility Bills }\end{array}$ & $\$ 150,000$ & $\$ 154,816$ \\
The True Monthly Cost of Home \\
Ownership \\
Monthly Savings & $\$ 135,000$ & $\$ 139,334$ \\
\hline
\end{tabular}

\subsection{Appraisal Industry Developments for Valuing Energy Efficiency}

Within the past year, significant industry developments have been achieved for the proper valuation of energy efficiency improvements. The following recent events and regulatory reforms are being recognized by the appraisal and financing industries as the leading drivers of ensuring energy efficiency improvements are being accounted for in the home appraisal process. 


\subsubsection{Dodd-Frank Wall Street Reform and Consumer Protection Act (HR 4173)}

On January 1, 2011, the Dodd-Frank Wall Street Reform and Consumer Protection Act (HR 4173) became a federal law (Frank 2009). The purpose of HR 4173 is to revamp the country's financial services regulatory system with more stringent institutional controls. It will serve as the first federal update of the country's real estate appraisal regulations since the Financial Institutions Reform, Recovery and Enforcement Act. HR 4173 has a significant impact on the appraisal industry, as it requires AMCs to collect competency information on all of their appraisers and keep it on file.

An additional requirement under HR 4173 that will have a significant impact on the proper valuation of energy efficiency improvements is that the homeowner must be provided with appraisal reports. Prior to HR 4173, it was up to the homeowner to request the report, and even then the appraiser was not obligated to provide this document. Now, however, the data and analysis of the home as listed in the appraisal report are transparent. Consequently, the homeowner has the opportunity to verify accuracy and check for errors or omissions.

\subsubsection{Introduction of Sustainable Building Science Education and Certification}

Since the implementation of HR 4173, the industry has begun to offer various educational training programs to encourage professionals in the housing, financing, and appraisal industries to gain more knowledge of sustainable building practices and learn how to recognize and properly assess energy efficient measures.

One such program is provided through the Appraisal Institute. The Valuation of Sustainable Buildings Professional Development Program offers appraisers (and any other industry professionals) three courses: Introduction to Green Buildings, Case Studies in Appraising Residential Green Buildings, and Case Studies in Appraising Commercial Green Buildings (Appraisal Institute). Also well regarded in the housing industry, the National Association of Realtors (NAR) has expanded its curriculum for the General Accredited Appraiser program to include an introduction to energy-efficient homes. For real estate practitioners (e.g., realtors), NAR also now offers "Green Designation" to provide ongoing education, resources, and tools so that those in the industry can successfully seek out, understand, and market residential and commercial properties with green features (NAR 2011a).

The development of green building training programs will be a continuous process, as more standards are implemented to support the proper valuation of energy efficiency measures, and concurrently, as more homeowners seek energy efficiency improvements. The development of all five industry improvements, HR 4371 (Frank 2009), Green MLS Tool Kit (NAR 2011b), Uniform Mortgage Data Program (Fannie), Appraisal Institute Addendum (Appraisal b), and Sustainable Building Education and Training (BIRA b), are interdependent with each other. Without each of these improvements, the industry would not be able to support valuations of energy efficiency improvements.

\subsubsection{Green MLS Tool Kit}

In April 2010, the NAR launched its Green MLS Tool Kit, which provides a step-by-step process that regional MLS databases can follow to include sustainable measures in their listings. The purpose of a Green MLS is to support the flow of sustainable home information in the 
marketplace and provide an educational resource for homebuyers, homeowners, realtors, and appraisers to use to develop a better understanding of sustainable homes.

Current MLSs neglect sustainable measures (including energy efficiency improvements). The tool kit provides a recommended process to build a Green MLS (or improve a current MLS) that allows listings of sustainable measures. A key concern from the housing, financing, and appraisal industries is the lack of data or access to supporting documentation for valuing energy efficiency improvements. A Green MLS would remediate this concern. The Green MLS Toolkit advises that documentation of a home's energy-efficient features become a part of the data exchange, captured in a Green MLS and/or a disclosure agreement with the home appraiser. Documentation is key to ensuring the proper valuation of energy efficiency improvements. Without documentation, the appraiser is limited to items that are visible and apparent. This would exclude many high-impact energy efficiency improvements such as wall insulation and low-e windows. As these items are often very cost effective, it is vital that such documentation is accessible.

The development of the Green MLS Tool Kit is pivotal for the proper valuation of energy efficiency. For homeowners interested in completing energy efficiency improvements, a Green MLS would enable them to see what types of improvements are common in the region and determine an estimate of value for said improvements. For appraisers, a Green MLS would support an apples-to-apples comparison for energy-efficient features. Without a Green MLS, the appraiser does not have sufficient information and data to support an assessment of energy efficiency improvements.

\subsubsection{Appraisal Institute Addendum}

In late September 2011, an addendum was issued by the Appraisal Institute for use with the Uniform Residential Appraisal Report (Appraisal A). The three-page form provides appraisers an opportunity to formally recognize energy efficiency improvements as a part of a home valuation assessment.

The addendum addresses not only energy efficiency, but also covers sustainable improvements such as water conservation measures and public transportation. The addendum will allow a homeowner to fill out a form, along with any supporting documentation (e.g., energy performance labels such as ENERGY STAR ${ }^{\circledR}$, or a HERS report) which indicates to the appraiser the expected energy savings. This provides a significant advantage over the traditional noninteractive appraisal process, especially for items such as insulation, which are not viewable at the time of appraisal.

As a key part of coming up with a valuation, appraisers using the new addendum will now be better equipped to identify accurate, recent "comparable" sales in the area. By using the addendum for a house with extensive energy efficiency improvements, an appraiser can look for prices of houses that were sold recently with and without energy efficiency improvements for assessing the home's true market value.

\subsubsection{Sensible Accounting to Value Energy Act}

The Sensible Accounting to Value Energy (SAVE) Act (Appendix B) was formally introduced on October 19, 2011, and at the time of publication was still under review by Congress. The SAVE Act is proposed legislation to improve the accuracy of underwriting used by federal 
lending agencies by ensuring that energy costs are included in the underwriting process. The SAVE act will require adding expected energy costs to the principal, interest, taxes, and insurance now entered into the equation when qualifying a borrower for a mortgage or a home improvement loan. The SAVE act is supported by a diverse coalition of organizations, including the U.S. Chamber of Commerce, the Appraisal Institute, the U.S. Green Building Council, and the Natural Resources Defense Council.

The SAVE Act would help revitalize the hardest hit sectors of the economy by providing financing for cost-effective energy improvements, enabling homeowners to recover the cost of efficiency investments and enabling better federal underwriting while lowering utility bills. With a more accurate analysis of repayment risk and the expect costs of homeownership, lenders will be better equipped to support the dispersal of energy efficiency improvement loans.

Moreover, the SAVE act will also greatly accelerate the demand for energy-efficient new homes. By consistently and accurately accounting for energy costs in appraisals, homebuilders and homeowners will be encouraged and enabled to invest in energy efficiency improvements.

\subsection{Improving Energy Efficiency Valuation Methods}

The major gap in financing energy efficiency retrofits for homeowners is properly valuing efficiency improvements. Until very recently, the appraisal industry has not had a set of industryvetted policies and practices for valuing energy efficiency in homes. Even with new policies and industry standards, without an established method to collect data and calculate the increase in the value of the home, lenders have difficulty determining how to consider the lower utility bills and the associated increase in property value when underwriting loans to homeowners. Thus, to ensure appropriate valuation and accounting of EEMs and strategies deployed, the appraiser should follow and account for the following:

\subsubsection{Identify Renewable Energy and Energy Efficiency Measures}

Before an appraiser can provide an increased valuation, he or she must be able to recognize the various renewable energy measures and EEMs in a home. Although all home appraisers are trained to identify types of building materials and how to assess items such as granite countertops, they are less likely to be knowledgeable about what constitutes an EEM and thus be able to accurately document those measures in a home. Green education and training will therefore be very beneficial to appraisers in developing this skill. It will be important for an appraiser to quickly and easily identify measures such as a photovoltaic system. Although the industry does not expect the appraiser to personally determine the energy savings estimates from such items, it is vital that appraisers are able to collaborate with those who do, such as home energy raters. A critical part of properly valuing energy efficiency is to determine the resulting energy cost savings. The appraiser should be able to view a home energy evaluation report and be able to identify and verify the items listed.

\subsubsection{Obtain a Home Energy Evaluation Report}

An appraiser of an energy-efficient home should obtain a home energy evaluation report. A home energy evaluation analyzes how a home is working as a system. Rather than reviewing the energy impacts of each component of the home separately, the operation of the home is analyzed by considering all of its energy-related components and how they interact. A trained and certified home energy assessor, also called a home energy rater, will inspect and perform the appropriate 
series of diagnostic tests on the home. The evaluation will consider the interactions of all measures and determine the whole-house performance as a system. The resulting home energy evaluation report will provide an appraiser an energy cost savings estimate.

\subsubsection{Assess the Value of Energy Efficiency Measures}

Currently, loans are made to homeowners for improvements that will have a predictable impact on home value and expenses. Homeowners' incomes include their investments, of which the home is generally the largest. If a homeowner would like to remodel the kitchen and add a deck to the rear of the house, a lender can turn to an appraiser to calculate the increase in the value of the home that will result from the improvements using the appraisal industry practices and rules based on long experience and historical data. The increase in home value translates to a future increase in income for a homeowner and results in a predictable level of risk for the lender. Without the ability to assess the value of energy efficiency improvements, a homeowner cannot receive the full benefit of the investment, as an increase in home value will not be applied and will likely not receive adequate lending opportunities because an unfair risk level is associated with the energy efficiency investment. Appraisers can and should use all available valuation data sources to assess the impact of an energy efficiency improvement.

The value of energy efficiency improvements could be assessed by unifying and integrating the many existing evaluation reports and components that are currently being used to support energy upgrades. Industry-accepted valuation tools include home energy evaluation reports and sustainable/energy efficiency certification standards (e.g., LEED, ENERGY STAR Home). The evaluation reports provide the appraiser an accurate estimate of expected energy cost savings. Using a standard return on investment analysis, the increased home value could be recognized as the difference between the incremental cost of the energy efficiency improvements and lifetime energy cost savings.

\subsection{Learning From Models Used in Commercial Appraisals}

Energy consumption in commercial and industrial buildings can be modeled and predicted more precisely because of more consistent and predictable occupancy patterns and behaviors. Because energy use in these types of buildings is predictable, the expected utility bill savings rendered through energy efficiency improvements can be much more accurately estimated.

Although most commercial appraisal methods are not used in the residential sector, there is potential to successfully extract and refine certain commercial appraisal practices and use them as tools in the ongoing improvement of the appraisal process in the residential sector on a large scale. These include the following two methods widely employed in commercial appraisals:

\subsubsection{Comparison With Documented Historical Data}

Commercial appraisals rely heavily on documented historical data (e.g., utility bill history), but this type of information may not always be available in the residential sector. For example, if an existing building is recently purchased (and the new building owner would like to complete an energy efficiency improvement) and no prior utility cost data are available, an appraiser, using a standard commercial appraisal practice, could rely on costs seen in similar buildings, or on data collected and published by recognized market sources. In the commercial sector, the Building Owners and Managers Association Experience Exchange Report or Institute of Real Estate Management Income/Expense Analysis Reports are two such examples. 


\subsubsection{Factoring in Operating Costs}

It is a well-established and widely used concept that operational costs are relevant to the value of an asset such as a house or building. In fact, for commercial buildings, adjustments to asset value typically result directly from changes to expected future operating costs. Dissimilarly, the residential financing industry traditionally has not examined the energy costs of a house in connection with determining the value of the house. This should be corrected to improve the reliability and integrity of both underwriting and valuation. 


\section{Discussion}

There is a cyclical interdependence of numerous industry stakeholders and factors in shaping the market - the market perception, market value, and market demand toward the inclusion of energy efficiency in the valuation and appraisal process. Appraisers cannot (and should not be expected to) create value and market demand directly and on their own; however, they are key stakeholders for successful market transformation. For energy efficiency to be recognized, the appraisal industry will need to support and standardize the documentation of energy efficiency improvement measures in reports. The market cannot begin to account for energy costs as an element in a property valuation if energy efficiency measures are not recognized and recorded as a standard part of appraisal reports. Although a valuation of all EEMs may be premature based on the current market status and the fact that energy efficiency improvements are not yet widely recognized in the market, nonetheless appraisal reports could provide the appropriate starting point for market transformation. The purpose of this research is not to discuss how the market must change so that the appraiser can report added value for energy efficiency improvements, but to identify through industry research what the current appraisal sector can do to help promote the market uptake of energy efficiency and the subsequent energy cost savings (less the increment measure costs) as potential added value.

Research results have indicated the residential appraisal industry has made - and continues to make - great strides toward establishing standard practices and methods for assessing the proper value of EEMs. However, there are still significant barriers to implementing and securing these improvements on an industry-wide scale. The first step to overcoming the barriers is to recognize the immediate issues and identify the source of the obstacles. Once done, a customized strategy can be developed to address the issues and the obstacles. Even while solutions are still being developed, there are current opportunities to ensure energy efficiency improvements are properly valued.

\subsection{Next Steps Toward Market Transformation}

The challenges to providing proper valuation of an energy-efficient home are numerous. There are concerns from appraisers about finding suitable comparable homes, having access to valuation data, and accounting for energy variables. The financing industry has difficulty assessing the risk of energy efficiency improvements and using the appraisal reports appropriately.

Overcoming these barriers will result in more energy-efficient homes and less overall energy consumption; lower utility bills for homeowners; improved underwriting practices; reduced risk of defaults; and the creation of green jobs in the real estate, home construction, and retrofit markets. Upon reviewing industry feedback and research, the following actions are recommended to standardize the valuation of energy efficiency improvements and increase the opportunity for financing of energy efficiency improvements.

\subsubsection{Increase Interactions Between Stakeholders}

Homeowners, underwriters, and appraisers can effectively resolve potential issues about lack of data or inaccurate risk assessments. The optimal method of communication is through the dissemination of energy efficiency reports and documentation (e.g., supporting data and evidence of energy efficiency improvements). Energy models, commissioning reports, energy audits, 
energy benchmarking scores, and other indicators of building performance and costs should be brought to the stakeholders' attention. Reports certified and vetted by third parties are especially valuable in this regard, as is information about potential utility or governmental incentives. It is the homeowner's responsibility to interact with the lender, the lender's responsibility to interact with the AMC, and the AMC's responsibility to interact with the appraiser.

Although direct communication and interaction between all stakeholder would be ideal, with the HVCC and HR 4173 restrictions, the best method of ensuring the energy efficiency improvements are recognized is to provide evidence to the appropriate point of contact. Homeowners can remind their lenders' of their responsibility, and suggest that as part of that responsibility, they ensure their appraisers (or AMC) has access to the provided documents and reports.

\subsubsection{Close Knowledge Gaps in Lender and Housing Industry}

There are several misconceptions about energy efficiency improvements in the financing and housing industries. For example, a common misunderstanding is that energy-efficient homes are not cost effective. However, energy-efficient homes are often more cost effective than homes built using traditional construction practice. By implementing education and training for professionals in the financing and housing industries, they will be better equipped to assess the true impacts of energy efficiency improvements. Increased knowledge of building science fundamentals will enable those in the industries to not only support, but also leverage energy efficiency improvements during the financing process.

\subsubsection{Develop and Expand Appraiser Education}

The appraisal and finance industries have been directly impacted by the new appraisal standards. With significant changes to the industries, it is vital that energy efficiency training and education is not only offered, but either required for licensing or provides a significant benefit (e.g., specific designation, certificate, or membership). As the appraisal industry expands its recognition of this issue, appraisers can expect to see several new courses and seminars to support their ongoing education for the valuation of energy efficiency.

\subsubsection{Update Traditional Home Appraisals Methods}

Prior to the creation of the Uniform Residential Appraisal Report addendum, the standard appraisal form was inadequate for capturing the information related to valuing and lending on energy-efficient homes. The new form has a provision for recording the type of energy efficiency certification, the year certified, if the home is third-party verified, and the home energy performance score, among other components. With the introduction of the addendum, the industry has provided an opportunity for appraisers to collect information and data about EEMs. Updates to the customary method of home appraisal will increase the likelihood that the addendum will be used.

Current appraisal methods rely heavily on market comparisons and industry data for valuations. Improvements will need to address how appraisers will process and factor in the valuation of energy efficiency improvements, building on the use of comparisons or significant data. New appraisal methods for energy efficiency will need to include an energy cost savings assessment for the proper valuation of homes. The updated appraisal methods should account for the savings from energy efficiency improvements to offset the cost of the investment. Unlike the process of 
assessing market value by using comparison to analysis of how the market is responding to specific building features (e.g., granite countertops), the expected annual energy cost savings (less the incremental costs of the energy efficiency improvements) can be a direct added value. To implement this update, adequate energy efficiency improvement cost databases will still need to be developed and implemented to support the appraiser analysis of the incremental cost for the EEMs.

\subsubsection{Develop Comparables and Valuation Database}

Appraisers must have access to reliable, verifiable data to support and defend their valuations of energy-efficient homes. MLSs provide appraisers a database of home parameters and corresponding values. Currently most MLS databases do not support the inclusion of energyefficient building features or home performance labels. The Green MLS Tool Kit was developed to support the industry's need for access to such data. However, the implementation and successful use of the tool kit are vital, and additional research is needed to understand the functionality and viability of improving MLS databases.

Searchable fields within MLS databases will be essential for appraisers to search for energyefficient comparisons and identify various energy-efficient building features or performance values. The current quality of energy efficiency data available on some MLS databases is suspect, as there are no standards for data uploading or modification. "Reduced days on market" can tell as powerful a story as premiums (evidence) for appraisers that consumers value EEMs. A green MLS that has searchable fields for energy-efficient entries will help appraisers to identify the market's response to energy-efficient items.

In support of developing and improving energy efficiency valuation databases, BIRA is currently participating in an academic research study, led by Lawrence Berkeley National Laboratory and the University of California, Berkeley for the development of methodologies for valuing green building labels. The study is evaluating if labeled homes demand a price premium in the marketplace. Under a nondisclosure agreement, U.C. Berkley has been provided BIRA's database of ENERGY STAR-labeled homes. This database represents more than 12,000 homes built since 2003. In brief, the research study will look at sales records of these homes and compare them to conventional homes to assess market value. The study results will provide supporting evidence and statistical data about the valuation of energy-efficient homes. This information can be used by the industry (e.g., the National Appraisers Institute) to leverage the development and enhancement of the appraisal process for energy-efficient homes.

\subsubsection{Understand Associated Risks of Variations in Occupant Behaviors, Plug Loads, and Weather}

Variations in occupant behaviors, plug loads, and weather conditions are considered substantial risks for lenders and appraisers. The level of risk associated with these issues is often not fully understood by the financing and appraisal industries. In the energy industry, significant research and analysis have been completed about the impacts of variations in occupant behaviors, plug loads, and weather. Energy modeling uses normalized data for such uncertainties. The variation in energy modeling and actual energy consumption has been accepted as a marginal difference in the building and energy industries. 
In 2006, BIRA evaluated the actual energy performance of near-zero energy homes against estimates using the simulation tools and best assumptions that were available at the time of construction. Equipped with updated information, models were revised to more closely simulate as-built and customer use information. BIRA found that electricity use was within $2 \%$ of expectations; actual gas use was overestimated by $25 \%$ using energy modeling and Building America benchmark assumptions for appliance, lighting, and miscellaneous energy use.

The financing and appraisal industries should be provided access to such studies and documentation of risk. Once lenders and appraisers become knowledgeable of the industryvetted energy modeling methodology, their confidence in using energy cost savings (as determined through energy modeling) will increase.

\subsection{Current Opportunities to Ensure the Proper Valuation of an Energy- Efficiency Retrofit}

At this time, there are limited regulations and standards for the valuation of energy efficiency improvements. However, homeowners and lenders can still leverage key appraisal standards and requirements to address the proper valuation of energy efficiency improvements.

\subsubsection{Request Quality Green Building Competence}

A homeowner or lender may ask for an appraiser who has experience in appraising green or energy-efficient homes or has received green building valuation training and certification from a nationally recognized appraisal entity (such as the Appraisal Institute or National Association of Real Estate Appraisers). Builders, lenders, and homebuyers legally can (and should) demand that AMCs assign only educated, experienced appraisers to energy-efficient homes. If in doubt, the client has the right to request a second opinion from another appraiser.

- Section 202(f) of the National Housing Act mandates that all appraisers chosen or approved to conduct appraisals of properties that will be security for FHA-insured mortgages must: (1) be certified by the state in which the property to be appraised is located; or by a nationally recognized professional appraisal organization; and (2) have demonstrated verifiable education in the appraisal requirements established by FHA. Additionally, it is important to note that when an appraiser signs a residential appraisal report form for a home with an FHA-insured mortgage, the appraiser is also certifying the following: "I have knowledge and experience appraising this type of property in this market area."

- Federal agencies such as Fannie Mae have guidelines in place that advise lenders (and AMCs) not to assume that an appraiser is competent:

A lender must not assume - simply based on the fact that an appraiser is statelicensed or state-certified - that the appraiser is qualified and knowledgeable about a market area or is aware of the appropriate market data sources for the area and will be able to obtain access to them. If an appraiser is not knowledgeable about a particular location, is not experienced in appraising a particular type of property or is not familiar with (or does not have access to) the appropriate data sources, a lender should not give the appraiser assignments in that market area or for that particular type of property. 


\subsubsection{Require Access to Valuation Guides}

Homeowners and lenders may require the appraiser to have access to green valuation guides such as the Marshall \& Swift Green Construction Cost Guide or other similar forms of energy efficiency valuation guides and databases for reference, including a Green MLS database. These provide valuable guidelines to assist with the appraisal process; for example, the Marshall \& Swift Green Construction Cost Guide includes real estate valuations studies that indicate an approximate \$20 home value should be added for each dollar saved annually on energy. An appraiser could use the estimated energy savings from a home's energy audit report (e.g., HERS report) to determine the approximate increase in home value.

\subsubsection{Provide Adequate Reporting}

Homeowners and lenders should provide to the AMC or appraiser any home energy performance reports and scores, as well as documentation of a home's green certification (e.g., ENERGY STAR or LEED). Until recently, standard appraisal forms did not adequately capture the information to value and lend on green homes. Appraisers are now equipped with improved forms (e.g., Form 1004 addendum) that can be used in conjunction with energy efficiency reports and documentation as evidence to support an increased home value. 


\section{Conclusions}

The financing and appraisal industries' momentum is shifting to recognize and value energyefficient homes. Research shows that the industries continue to make significant progress toward implementing a more granular approach to account for an important cost of homeownership, energy. With a better understanding of the role of energy in the true cost of homeownership, appraisers and lenders can recognize the lack of accounting for energy as a significant barrier to the proper valuation and financing of energy efficiency improvements.

There is a cyclical interdependence of numerous industry stakeholders and factors in shaping the market demand, value, and perception of including energy efficiency as an integral part of valuation and home appraisals. Appraisers cannot create the market demand or the value on their own; however, they are key stakeholders for successful market transformation.

Numerous challenges lie ahead for the development of adequate valuation for energy efficiency, but there are equally significant opportunities to continue industry progress and close the gap for homeowners obtaining proper valuation and financing for energy efficiency. Some improvement opportunities directly target specific issues (such as the lack of valuation sources for energy efficiency improvements); others would work to heighten collaboration between stakeholders. The result of identifying and responding to the barriers for the proper valuation of energy efficiency will impact more than just the financing and appraisal industry. With increased valuation of energy efficiency improvements and increase in financing opportunities, more homeowners will become interested in completing energy efficiency improvements and lowering their monthly energy costs. Consequently, proper valuation will also encourage investment in energy efficiency, create jobs, and increase energy independence benefits. 


\section{References}

Appraisal Foundation, Uniform Standards of Professional Appraisal Practice.

http://www.uspap.org/

Appraisal Institute, The Appraisal of Real Estate, 13th Edition

Appraisal Institute, Residential Green and Energy Efficient Addendum, http://www.appraisalinstitute.org/education/downloads/AI_82003_ReslGreenEnergyEffAddendu m.pdf

Appraisal Institute, Valuation of Sustainable Buildings Professional Development Program, http://www.appraisalinstitute.org/education/green/default.aspx

Barris, J. (2008) An expert system for appraisal by the method of comparison. PhD Thesis, UPC, Barcelona

Baum, A. and Mackmin, D. (1995) The Income Approach to Property Valuation (3rd Edition). Routledge, London

BIRA, Guide to Financing Strategies for Residential Energy Efficiency Retrofits, January 2011, Stockton, CA, Building Industry Research Alliance

BIRA, Final Expert Meeting Report: The Role of Appraisals in Retrofit Financing, September 2011, Stockton, CA, Building Industry Research Alliance, http://www.bira.ws/energy-retrofitfinancing.php

BIRA, Occupied Home Evaluation Results Report, November 2006, Sacramento, CA, Building Industry Research Alliance, http://www.bira.ws/files/reports/Final_Report_16D2_OccupiedHomeEvaluationResults.pdf

Brown, G.R. and Matysiak, G.A. (1999) Real Estate Investment: A Capital Market Approach. Financial Times, London

Faesy, Richard (2000), "Understanding and Overcoming the Energy Mortgage Barrier," ACEEE Summer Study on Energy Efficiency in Building.

Fannie Mae, Form 1004: Uniform Residential Appraisal Report, https://www.efanniemae.com/sf/formsdocs/forms/1004.jsp

Federal Housing Finance Agency (FHFA), Home Valuation Code of Conduct, 2008, http://www.fhfa.gov/webfiles/2302/HVCCFinalCODE122308.pdf

Fannie Mae, Uniform Mortgage Data Program, https://www.efanniemae.com/sf/lqi/umdp/

Frank, Barney, H.R. 4173: Dodd-Frank Wall Street Reform and Consumer Protection Act, http://www.govtrack.us/congress/bill.xpd?bill=h111-4173 
Institute for Market Transformation, Average U.S. Homeowner Costs 2008 Energy Property Tax, http://www.imt.org/files/

Isaac, D. (2002) Property Valuation Principles, Palgrave, London

Kane, S., Linne, M. and Johnson, J. (2004) Practical Applications in Appraisal Valuation Modeling. Appraisal Institute, Chicago

Maliene, V., Deveikis, S., Kirsten, L. and Malys, N. (2010). "Commercial Leisure Property Valuation: A Comparison of the Case Studies in UK and Lithuania". International Journal of Strategic Property Management 14 (1): 35-48. doi:10.3846/ijspm.2010.04.

National Association of Realtors (2011), Green Designation, http://www.greenresourcecouncil.org/earn_nars_green_designation.cfm

National Association of Realtors (2011), The Green MLS Tool Kit, http://greenthemls.org/

Rees, W.H. and Hayward, R.E.H. (ed.) (2000) Valuation: Principles into Practice (5th edition). Estates Gazette

Sensible Accounting to Value Energy Act of 2011, rhttp://www.gpo.gov/fdsys/pkg/BILLS112s1737is/pdf/BILLS-112s1737is.pdf

Simons, Robert (2007) When Bad Things Happen to Good Property Environmental Law Institute, Washington, DC

U.S. Census Bureau, 2009 American Community Survey 


\section{Appendix A: Appraisal Regulations and Standards}

The home appraisal industry has several collaborative professional organization and regulating entities which work together to provide performance standards and recommended practices. One of the most prevalent and influential appraisal organizations is the Appraisal Foundation, whose mission is to promote professionalism in appraising. Although not federally-funded, the Appraisal Foundation is responsible for providing recommendations to congress regarding the following minimum criteria for state licensed/certified real property appraisers.

Table 2. Recommended Minimum Criteria for State Licensed/Certified Appraisers

\begin{tabular}{c|c|c|c}
\hline Type & Experience & Education & Exam \\
\hline Licensed Residential & 2,000 hours & 150 hours & Yes \\
Certified Residential & 2,500 hours & 200 hours & Yes \\
Certified General & 3,000 hours & 300 hours & Yes \\
\hline
\end{tabular}

Moreover, the Appraisal Foundation's Appraisal Standards Board promulgates the performance standards of the appraisal profession, known as the Uniform Standards of Professional Appraisal Practice. Also, a part of the Appraisal Foundation, the Appraiser Qualifications Board is responsible for developing and maintaining appraisal criteria. The criterion outlines minimum requirements in the areas of education, experience and continuing education. The federal government mandates that each state's appraiser regulatory agencies must use the Criteria adopted by of the Appraisal Foundation when issuing certificates to individuals.

Although minor variations exist, most requirements, governing regulations, and standards are consistent across all states. Appraisers are required to be licensed or certified through their state. Individuals seeking to become state licensed or certified appraisers must pass a comprehensive state examination that has been reviewed and approved by the Appraiser Qualifications Board. As a professional appraiser, they are required to adhere to the National Association of Real Estate Appraisers Code of Ethics and the performance standards of the Uniform Standards of Professional Appraisal Practice.

Prior to the introduction of the Frank-Dodd Wall Street Reform and Consumer Protection Act (HR 4173 Act), an additional requirement for all appraisal of homes with federal loans (include those sold to Fannie Mae or Freddie Mac) was the HVCC. The HVCC mandated that lenders separate anyone on the sales side of the business (loan originators, loan officers and loan processors) from appraisers. As a "prudent safeguard" to ensure that an appraiser's valuation analysis is not influenced, "Appraisal Management Companies" (MCs) were developed for the sole purpose of separating the appraiser from the lender. 


\section{U.S. DEPARTMENT OF Energy Efficiency \& ENERY Renewable Energy}

